\title{
Factors Related to the Standard Operating Procedure Compliance of the Workers at PT X
}

\author{
Faktor yang Berhubungan dengan Kepatuhan Pelaksanaan Standard \\ Operating Procedure pada Pekerja PT X
}

\author{
Firda Rahmawati \\ Dr. Soetomo Surabaya Regional Hospital \\ Jalan Mayjen Prof. Dr. Moestopo No. 6-8 Gubeng, Surabaya, East Java, Indonesia 60286
}

\begin{abstract}
Introduction: Each company has its Standard Operational Procedure that is used as a standard for workers to work safely. SOPs are established and implemented to minimize the hazards of accidents in the workplace. As one of the largest automotive manufacturing companies in Indonesia, PT X also has the potential hazards of occupational accidents. The existence of accidents at the company is caused by unsafe behavior. The purpose of this study is to analyze the correlation between individual characteristics, training, knowledge, as well as motivation and the SOP compliance at PT X. Methods: This research is observational research with the crosssectional design. The samples of this research were 30 workers. The samples were taken by using the simple random sampling method. The data collection was obtained from the results of questionnaires, interviews, and observations, while the supporting data in the form of secondary data was taken from the related SOP. Results the variable of individual characteristics in the form of age and working period are not related to the behavior of SOP compliance. The variables of worker training, knowledge, and motivation are related to SOP compliance behavior tested with the statistical test showed the p-values of $0.008,0.000$, and 0.022 . Conclusion: The individual characteristics of age and working period cannot describe the behavior of SOP compliance, while the individual characteristics of training, knowledge, and motivation can improve the SOP compliance.
\end{abstract}

Keywords: motivation, SOP compliance, training

\section{ABSTRAK}

Pendahuluan: Setiap perusahaan memiliki Standard Operational Procedure (SOP) yang digunakan sebagai standar pekerja dalam melaksanakan pekerjaan secara aman. SOP dibuat dan dilaksanakan untuk meminimalisir bahaya kecelakaan di tempat kerja. Pada perusahaan manufaktur pembuatan mobil PT X yang merupakan salah satu perusahaan otomotif terbesar di Indonesia juga memiliki potensi bahaya terhadap kecelakaan kerja. Adanya kecelakaan di perusahaan disebabkan oleh perilaku pekerja yang tidak aman. Tujuan penelitian ini adalah untuk menganalisis hubungan antara karakteristik individu, pelatihan, pengetahuan dan motivasi dengan kepatuhan SOP di PT X. Metode: Penelitian ini merupakan penelitian observasional dengan desain cross sectional. Sampel penelitian ini sebesar 30 pekerja di bagian CEVD PT X. Sampel diambil dengan menggunakan metode simple random sampling. Pengumpulan data didapatkan dari hasil kuesioner, wawancara dan observasi serta data pendukung berupa data sekunder dari perusahaan terkait SOP. Hasil: Variabel karakteristik individu berupa umur dan masa kerja tidak ada hubungan dengan perilaku kepatuhan SOP. Variabel pelatihan, pengetahuan dan motivasi berhubungan dengan perilaku kepatuhan SOP dengan hasil uji statistik menunjukkan p-value sebesar 0,008; 0,000 dan 0,022. Simpulan: Semakin tinggi karakteristik individu berupa umur dan masa kerja individu tidak dapat menggambarkan perilaku kepatuhan SOP, sedangkan semakin tinggi pelatihan, pengetahuan dan motivasi pekerja dapat meningkatkan kepatuhan terhadap SOP.

Kata kunci: kepatuhan SOP, motivasi, pelatihan

Corresponding Author:

Firda Rahmawati

Email: firdarahma24@gmail.com

C2019 IJOSH All right reserved. Open access under CC BY NC-SA license doi: 10.20473/ijosh.v8i2.2019. 197-205

Received July 10, 2018, received in revised form February 07, 2019, Accepted August 02, 2019, Published: August 2019 


\section{INTRODUCTION}

Indonesia is a developing country, which is currently maximizing its economic growth through the industrial sector. The development of the industrial sector requires labor as one of the resources to run the company. However, in the development, several emerging impacts affect the loss of workers, among which, is occupational accidents. Occupational accidents are unwanted and unexpected events which incur the loss of time, property, and even casualties in the industrial work process (Tarwaka, 2016). The report of the International Labour Organization (ILO) mentioned that annually, on average of three days, 270 million people experience non-fatal accidents and 160 million people suffer from occupational diseases (Dewi, 2010). The Indonesian Social Security for Employment (BPJS Ketenagakerjaan) stated that the number of occupational accidents until the end of 2015 had reached 105,182 cases and 2,375 cases among them were the cases of severe injury. The number of occupational accidents in Indonesia has experienced a trend of increasing by up to 5\% annually (The Indonesian Social Security for Employment, 2016).

Occupational accidents have the potential to occur in all companies, both in the small-scale and large-scale companies. Automotive manufacturing companies are no exception since the work poses enormous potential hazards. The manufacturing steps start with the hightemperature steel casting until the car components are formed. The car engine and component manufacturing process end with the car assembly and welding. The high number of accidents and potential hazards in every industry require prevention by understanding the factors that affect the occurrence of occupational accidents so that they can be controlled. PT X is one of the largest automotive manufacturing companies in Indonesia, which produces and exports vehicle products and official spare parts. PT X produces cars, including the components, engines, frames, and all parts of cars. The production results are then marketed for the domestic and foreign markets.

PT X consists of three plants, i.e., Plant 1 (Engine and Vanning), Plant 2 (Casting and Stamping), and Plant 3 (Assembly, Welding, and Painting). Plant 1 comprises two production divisions, i.e., the car engine manufacturer and the car component packing. The car component packing of Component Export Vanning Division (CEVD) includes the wiring, supply, picking, and stacking processes. The processes in the division have potential hazards, which can cause accidents.

The previous study at PT X suggested that there were several occupational accidents at CEVD in 2015. The occupational accidents caused injury to one of the workers who then required medical treatment. The occupational accidents occurred due to the workers' unsafe behavior and condition so that his arm was cut by a sharp component. However, in the following year until the present, the number of occupational accidents has decreased.

Bird and Germain (1985) proposed the theory of Loss Causation Model and modified the theory of accident according to Heinrich's domino theory, in which they argued that accident could occur due to the lack of control, basic causes, immediate causes, incident, and losses. The "domino" factors causing the accident affects each other sequentially. If a factor occurs, it will affect other factors, which will cause the occupational accidents.

Bird and Germain (1985) stated that the weak control is caused by the inadequate management program, insufficient program standard, and inappropriate standard fulfillment. The second "domino" is the basic cause that consists of personal and work factors. The basic causes can explain the occurrence of substandard practice and substandard condition, which become two immediate causes. Immediate causes are the factors affecting the occurrence of an accident, so the accident control usually omits one of the dominoes, i.e., the substandard practices or substandard conditions (Kuswana, 2016).

One of the substandard practices committed by workers is not complying with the Standard Operating Procedure or SOP. The Standard Operating Procedure is a set of instructions, steps, or stages of the activities that should be carried out in a certain work process to maintain the certain level of performance or condition so that the activities can be completed effectively and efficiently. SOPs are established by companies with several purposes, including preventing the workers from the possibilities of occupational accidents.

The research of Noviyanti (2017) regarding the analysis of the correlation between the factors causing occupational accidents and the substandard practices at PT PAL Indonesia 
claimed that there were 52 or approximately $72.2 \%$ out of 72 respondents who do not behave safely. In this research, the non-compliance occurs in the welding department employees, while the remaining 20 respondents or $27.8 \%$ behaved safely while working. The unsafe behavior was caused by the lack of knowledge, policy, supervision, PPE provision, and commitment from the management regarding OSH. The research at PT SIM mentioned that there was still unsafe behavior, amounting roughly $16.2 \%$ out of the total 130 samples occurring from the workers' lack of knowledge and motivation. The workers who acquired a low level of knowledge $(88.9 \%)$ did more unsafe behavior than those with a higher level of knowledge. Likewise, the workers who had low motivation tended to commit more unsafe behavior $(89.5 \%)$ than those with high motivation (Halimah, 2010).

From the results of the previous studies, there are several factors that can render the accident, i.e., personal factors and motivation factors. Personal factors consist of the workers' knowledge and motivation while the management factors comprise of the lack of worker training, and unsafe behavior factors, i.e., SOP non-compliance. This research aims at analyzing the correlation between the factors causing an accident, i.e., worker training, knowledge, motivation, as well as age, and the workers' SOP compliance. This research is expected to be useful for companies to reduce the number of SOP non-compliance and accident cases.

\section{METHODS}

The method used in this research was the observational research since the researcher only conducted an observation to the respondents without giving any special treatment. Based on nature and time, this was included into the crosssectional analytical research since it was conducted at a time and the results of the study would be analyzed and presented in the form of tables and description.

This research was conducted at the CEVD of PT X in April 2018. The total population was 33 workers, and the samples were taken by using the simple random sampling formula.

$$
n=\frac{z_{1-\frac{\alpha}{2}}^{2} P(1-P) N}{d^{2}(N-1)+z_{1-\frac{\alpha}{2}}^{2} P(1-P)}
$$

$$
\begin{gathered}
n=\frac{1,96^{2} \times(0.5(1-0.5)) 33}{0.05^{2}(33-1)+1.96^{2} \times 0.5(1-0.5)} \\
n=\frac{31.6932}{1.0404} \\
n=30
\end{gathered}
$$

From the sampling technique using the simple random sampling method, the study samples were 30 workers. The sampling technique was conducted randomly without regarding the work strata so that the sampling technique was in accordance with the workers who took the rest first.

The employed variables were the dependent variables, which included individual characteristics, training, knowledge, and motivation, and the independent variable, consisting of the workers' compliance toward SOP.

The utilized data was primary and secondary data. The primary data were obtained from the questionnaire of individual characteristics, which included the followings: the respondents' age and working period; the interview with the HSE and safety officer regarding the $\mathrm{OSH}$ program, OSH training, and SOP in the company; and direct observation using the Critical Behavior Checklist based on SOP compliance.

The SOP used was the instruction in carrying out the work. Meanwhile, the secondary data was the company's data of occupational accidents and SOP.

The obtained data were then processed and analyzed using the correlation test to discover the correlation between the data with ordinal data scale level and chi-square to find the correlation between the data with nominal data scale level.

\section{RESULTS}

The research results were based on the questionnaire answers and observation at the Component Export Vanning Division (CEVD) of PT X regarding age, working period, worker training, knowledge, motivation, and SOP compliance toward 30 workers on three plants, i.e., Plant 1 (Engine and Vanning), Plant 2 (Casting and Stamping), and Plant 3 (Assembly, Welding, and Painting). 


\section{Univariate Analysis}

From the results of Table 1, it can be deduced that out of 30 respondents, 19 respondents $(63.3 \%)$ considered that the training held by the management had not been optimal yet. Most of the respondents had not followed the training in the company since the needs of training at PT X was highly occupied, and only several worker representatives were enrolled to follow the training.

The dominant age of respondents was in the range of less than 25 years old, amounting to 17 respondents $(56.7 \%)$. Therefore, most of the workers at CEVD of PT X were considered young and productive. The situation takes place because almost every year, PT X carries out worker recruitment resulting in many workers in still young age.

Table 1. The Frequency of Worker Training, Age, Working Period, Knowledge, Motivation, and SOP Compliance at PT X in 2018

\begin{tabular}{clcc}
\hline Variable & Category & Total & $\begin{array}{c}\text { Percentage } \\
(\%)\end{array}$ \\
\hline \multirow{2}{*}{ Worker } & Low & 19 & $63.3 \%$ \\
Training & Moderate & 4 & $13.3 \%$ \\
& High & 7 & $23.3 \%$ \\
\hline \multirow{2}{*}{ Age (Year) } & $<25$ & 17 & $56.7 \%$ \\
& $25-35$ & 12 & $40 \%$ \\
Working & $>35$ & 1 & $3.3 \%$ \\
\hline \multirow{2}{*}{ Period } & $5-10$ & 15 & $50 \%$ \\
& $>10$ & 6 & $20 \%$ \\
Knowledge & Low & 9 & $30 \%$ \\
& Moderate & 10 & $33.3 \%$ \\
& High & 11 & $30 \%$ \\
\hline \multirow{2}{*}{ Motivation } & Low & 8 & $36.7 \%$ \\
& Moderate & 13 & $26.7 \%$ \\
& High & 9 & $33.3 \%$ \\
\hline \multirow{2}{*}{ SOP } & Not & 18 & $60 \%$ \\
Compliance & Complying & 12 & $40 \%$ \\
& Complying & 12 & \\
\hline \multirow{2}{*}{ Com } & &
\end{tabular}

The highest frequency of respondents' working period was less than five years, amounting to 15 respondents (50\%). Thus, they can be considered a lack of work experience.

The number of respondents with a high knowledge level reached 11 respondents (36.7\%), while the ones with low knowledge level amounted to 10 respondents (33.3\%). Thus, workers with low knowledge were the majority.

Thirteen respondents $(43.43 \%)$ had a moderate level of motivation, which means that the workers' motivation at CEVD of PT X was relatively low.

The compliance level indicated that most of the workers at the CEVD of PT X, 18 respondents, or $60 \%$, did not comply with the SOP or work instruction established by the company management. It can be deduced that the workers' unsafe behavior was still high.

At the CEVD, there were two observed sections, i.e., the boxing and wiring work processes. The observation results on item 2 , and Item 3 were observed by looking at the SOP set by the company. If during the observation, there were workers who did not comply with the SOP, they would be considered not to behave safely, although they only violated one point from the SOP. The observation utilizes the Critical Behavior Checklist.

Table 2. Observation Result of the Workers' SOP Compliance at PT X in 2018

\begin{tabular}{lcc}
\hline \multicolumn{1}{c}{ Variable } & \multicolumn{2}{c}{ Behavior } \\
\hline \multicolumn{1}{c}{ SOP Compliance } & Safe & Unsafe \\
\hline $\begin{array}{l}\text { Workers conduct } \\
\text { initial checking on the }\end{array}$ & 20 & 10 \\
$\begin{array}{l}\text { work environment } \\
\text { before working }\end{array}$ & $(66.67 \%)$ & $(33.33 \%)$ \\
$\begin{array}{l}\text { Workers follow the } \\
\text { work instruction in }\end{array}$ & 23 & \\
$\begin{array}{l}\text { accordance with the } \\
\text { SOP }\end{array}$ & $(76.67 \%)$ & $(23.33 \%)$ \\
$\begin{array}{l}\text { Workers do not skip } \\
\text { the work instruction }\end{array}$ & $(76.67 \%)$ & $(23.33 \%)$ \\
$\begin{array}{l}\text { Workers work } \\
\text { carefully and seriously } \\
\begin{array}{l}\text { Workers conduct final } \\
\text { checking after }\end{array}\end{array}$ & $(33.33 \%)$ & $(66.67 \%)$ \\
working & 10 & 14 \\
\hline
\end{tabular}

\section{Bivariate Analysis}

\section{Age and SOP Compliance}

Table 3. The Correlation between Age and SOP Compliance at PT X in 2018

\begin{tabular}{|c|c|c|c|c|}
\hline \multirow[b]{2}{*}{ Age } & \multicolumn{2}{|c|}{ SOP Compliance } & \multirow[b]{2}{*}{ Total } & \multirow[b]{2}{*}{$\begin{array}{c}\text { p- } \\
\text { value }\end{array}$} \\
\hline & $\begin{array}{c}\text { Not } \\
\text { Complying }\end{array}$ & Complying & & \\
\hline$<25$ & 11 & 6 & 17 & \multirow{6}{*}{0.551} \\
\hline years & $(64.7 \%)$ & $(35.3 \%)$ & $(100 \%)$ & \\
\hline $25-35$ & 7 & 5 & 12 & \\
\hline years & $(58.3 \%)$ & $(41.7 \%)$ & $(100 \%)$ & \\
\hline$>35$ & 0 & 1 & 1 & \\
\hline years & $(0 \%)$ & $(100 \%)$ & $(100 \%)$ & \\
\hline
\end{tabular}


Table 3 illustrates that most of the respondents who were in the age range of less than 25 years old and did not comply with the SOP reached 11 respondents out of 17 respondents $(64.7 \%)$. The workers who mostly complied with the SOP were also in the age range of less than 25 years, amounting to six respondents $(35.3 \%)$. From the statistical test result, the $p$-value reached 0.551 that was greater than the $\alpha$-value (0.05). This finding means that there was no correlation between workers' age and SOP compliance. In other words, the workers' age did not necessarily guarantee their compliance toward the SOP at CEVD of PT X.

\section{Working Period and SOP Compliance}

Table 4. The Correlation between Working Period and SOP Compliance at PT X in 2018

\begin{tabular}{|c|c|c|c|c|}
\hline \multirow[b]{2}{*}{$\begin{array}{c}\text { Working } \\
\text { Period }\end{array}$} & \multicolumn{2}{|c|}{ SOP Compliance } & \multirow[b]{2}{*}{ Total } & \multirow[b]{2}{*}{$\begin{array}{c}\text { p- } \\
\text { value }\end{array}$} \\
\hline & $\begin{array}{c}\text { Not } \\
\text { Complying }\end{array}$ & Complying & & \\
\hline $\begin{array}{c}<5 \\
\text { years }\end{array}$ & $\begin{array}{c}10 \\
(66.7 \%)\end{array}$ & $\begin{array}{c}5 \\
(33.3 \%)\end{array}$ & $\begin{array}{c}15 \\
(100 \%)\end{array}$ & \\
\hline $\begin{array}{l}5-10 \\
\text { years }\end{array}$ & $\begin{array}{c}4 \\
(66.7 \%)\end{array}$ & $\begin{array}{c}2 \\
(33.3 \%)\end{array}$ & $\begin{array}{c}6 \\
(100 \%)\end{array}$ & 0.612 \\
\hline $\begin{array}{l}>10 \\
\text { years }\end{array}$ & $\begin{array}{c}4 \\
(44.4 \%)\end{array}$ & $\begin{array}{c}5 \\
(55.6 \%)\end{array}$ & $\begin{array}{c}9 \\
(100 \%)\end{array}$ & \\
\hline
\end{tabular}

From the results on Table 4, it can be seen that the respondents who do not comply with the SOP mostly have the working period of less than 5 years, that is as many as $10(66.7 \%)$ out of 15 respondents in the similar working period category. Based on the statistical test result, the obtained p-value was 0.612 greater than $\alpha$-value (0.05), which means that there is no correlation between the working period and SOP compliance. It indicates that the length of the working period cannot ensure compliance with the SOP at the CEVD of PT X.

\section{Worker Training and SOP Compliance}

From Table 5, it can be seen that the workers who have low training tend to not comply with the SOP, in which it comprises 13 $(68.4 \%)$ out of 19 respondents who have low training. From the statistical test result, the obtained p-value is 0.008 less than $\alpha$-value (0.05). This finding means that there was a correlation between training and SOP compliance. Thus, the training received by the workers can guarantee the level of SOP compliance of the workers at the CEVD of PT $\mathrm{X}$.

Table 5. The Relationship between Worker Training and SOP Compliance of the Workers at CEVD of PT X in 2018

\begin{tabular}{ccccc}
\hline $\begin{array}{c}\text { Worker } \\
\text { Training }\end{array}$ & \multicolumn{2}{c}{ SOP Compliance } & Tot \\
\cline { 2 - 3 } & $\begin{array}{c}\text { Nomplying } \\
\text { Complying }\end{array}$ & Com- & $\begin{array}{c}\text { p- } \\
\text { value }\end{array}$ \\
\hline Low & 13 & 6 & 19 & \\
& $(68.4 \%)$ & $(31.6 \%)$ & $(100 \%)$ & \\
Moderate & 4 & 0 & 4 & $\mathbf{0 . 0 0 8}$ \\
& $(100 \%)$ & $(0 \%)$ & $(100 \%)$ & \\
High & 1 & 6 & 7 & \\
\hline
\end{tabular}

\section{Knowledge and SOP Compliance}

Table 6. The Correlation between Knowledge and SOP Compliance at PT X in 2018

\begin{tabular}{|c|c|c|c|c|}
\hline \multirow[b]{2}{*}{ Knowledge } & \multicolumn{2}{|c|}{ SOP Compliance } & \multirow[b]{2}{*}{ Total } & \multirow[b]{2}{*}{$\begin{array}{c}\text { p- } \\
\text { value }\end{array}$} \\
\hline & $\begin{array}{c}\text { Not } \\
\text { Complying }\end{array}$ & Complying & & \\
\hline Low & $\begin{array}{c}10 \\
(100 \%)\end{array}$ & $\begin{array}{c}0 \\
(0 \%)\end{array}$ & $\begin{array}{c}10 \\
(100 \%)\end{array}$ & \\
\hline Moderate & $\begin{array}{c}8 \\
(88.9 \%)\end{array}$ & $\begin{array}{c}1 \\
(11.1 \%)\end{array}$ & $\begin{array}{c}9 \\
(100 \%)\end{array}$ & 0.000 \\
\hline High & $\begin{array}{c}0 \\
(0 \%)\end{array}$ & $\begin{array}{c}11 \\
(100 \%)\end{array}$ & $\begin{array}{c}11 \\
(100 \%)\end{array}$ & \\
\hline
\end{tabular}

The results in Table 6 present that 10 respondents $(100 \%)$ who did not comply with the SOP had a low level of knowledge. The results also indicate that the workers with low and moderate levels of knowledge mostly did not comply with the SOP, while all workers who had a high level of knowledge complied with the SOP. Based on the statistical test result, the obtained p-value was 0.000 , which was less than $\alpha$-value (0.05). This finding means that there is a correlation between knowledge and the workers' SOP compliance at the CEVD of PT X, which can be deduced that the level of knowledge ensures the level of compliance toward the SOP of the workers at the CEVD of PT X.

\section{Motivation and SOP Compliance}

Table 7 demonstrates that most respondents who did not comply with the SOP had the moderate motivation, amounting to 9 respondents $(69.2 \%)$. The statistical test result found that the p-value of 0.022 was less than $\alpha$ value (0.05). This finding means that there was 
a correlation between motivation and the workers' SOP compliance. Therefore, the workers' motivation can determine the level of SOP compliance of the workers at the CEVD of PT X.

Table 7. The Correlation between Motivation and SOP Compliance at PT X in 2018

\begin{tabular}{|c|c|c|c|c|}
\hline \multirow{2}{*}{$\begin{array}{l}\text { Motiv } \\
\text { ation }\end{array}$} & \multicolumn{2}{|c|}{ SOP Compliance } & \multirow[b]{2}{*}{ Total } & \multirow[b]{2}{*}{ p-value } \\
\hline & $\begin{array}{l}\text { Not } \\
\text { Complying }\end{array}$ & Complying & & \\
\hline Low & $\begin{array}{c}7 \\
(87.5 \%)\end{array}$ & $\begin{array}{c}1 \\
(12.5 \%)\end{array}$ & $\begin{array}{c}8 \\
(100 \%)\end{array}$ & \\
\hline $\begin{array}{l}\text { Moder } \\
\text { ate }\end{array}$ & $\begin{array}{c}9 \\
(69.2 \%)\end{array}$ & $\begin{array}{c}4 \\
(30.2 \%)\end{array}$ & $\begin{array}{c}13 \\
(100 \%)\end{array}$ & 0.022 \\
\hline High & $\begin{array}{c}2 \\
(22.2 \%) \\
\end{array}$ & $\begin{array}{c}7 \\
(77.8 \%) \\
\end{array}$ & $\begin{array}{c}9 \\
(100 \%) \\
\end{array}$ & \\
\hline
\end{tabular}

\section{DISCUSSION}

PT $\mathrm{X}$ is one of the largest automotive manufacturing companies in Indonesia, which carries out the official vehicle product assembly as well as vehicles and spare parts exporter. This company markets its products to domestic and foreign markets. The products of this company are components, engines, frames, and all parts of cars.

From the obtained results, it is known that worker training is mostly in the low category with a percentage of $63.3 \%$. The results indicate that the training held by the management is still low, so most of the respondents have not attended the worker training in the company since only several workers are chosen to attend the training. The respondents' age mostly falls into the category of less than 25 years, with the percentage of $56.7 \%$. It indicates that the workers at PT X are mostly in the productive age. It happens because this company often recruits new workers, giving the company many young workers. The respondents' working period was mostly less than five years, with a percentage of $50 \%$. Therefore, it can be concluded that most workers at the company had a lack of work experience.

The respondents' knowledge mostly falls into the high category, with a percentage of $36.7 \%$. However, the percentage is also not much different from the number of workers who had a low level of knowledge, amounting to $33.3 \%$. It indicates that the workers with high and low levels of knowledge almost had the same figure. The workers' motivation at the
CEVD of PT X mostly falls into the moderate category with the percentage of $43.43 \%$, which shows that the workers' motivation at the CEVD of PT X was relatively low. Regarding the workers' compliance, the results demonstrate that most of the workers at PT X did not comply with the SOP or work instruction at the company, with a percentage of $60 \%$. It indicates that many workers did not follow the right procedure when doing their work. This situation can generate the possibility of occupational accidents which will affect the workers' safety.

The variables of SOP compliance that generate safe behavior are the variable of workers who obey the work instruction in accordance with the SOP and workers who did not deviate from the work instruction. From the interview result with the workers at the CEVD of PT X, it is identified that there was a worker who had an accident due to negligence at the workplace. The result is in line with the statement of Heinrich (1980) who argued that most occupational accidents are caused by human and substandard practice factors with the percentage of $85 \%$, while the rest is the substandard condition factor.

\section{Age and SOP Compliance}

The correlation between age and SOP compliance of the workers at PT X shows that there was no correlation between both variables. This indicates that the younger or, the older the workers' age would not affect the workers' compliance toward the SOP at the CEVD of PT $X$. These results are in line with the research conducted by Ulfa and Sarzuli (2016) on nurse compliance in carrying out the SOP of catheter installation at PKU Muhammadiyah Yogyakarta Hospital Unit II which demonstrated that age has not to influence to the nurse compliance in carrying out the SOP of catheter installation. The lack of correlation between both variables is because most workers at PT X are young, that is under 25 years old. The research is in line with the research conducted by Patria (2017), which showed that the age variable does not correlate with the workers' compliance toward the SOP. This research is not in line with the statement argued by Suma'mur (2014) which stated that the older the worker, the more careful he does his work, so he understands more about the risk of danger at the workplace than the younger workers. 


\section{Working Period and SOP Compliance}

The results of this study indicate that there is no correlation between the working period and SOP compliance. It shows that working period did not affect the compliance toward the SOP. The longer working period would not influence the workers' compliance toward the SOP. These results are not in line with the research conducted by Dewi (2010) on the workers at PT Suzuki Indomobil Motor-Roda 4 Plant Tambun II Bekasi which demonstrated that the longer working period does not have any meaningful correlation with the compliance in carrying out the work SOP. It can be deduced that way since there are still workers with a long working period, that is more than ten years, who do not comply with the SOP. Therefore, it can be concluded that the working period cannot guarantee that someone will comply with the SOP. Workers with longer working period have more experience than workers with a shorter working period, so the workers with the working period of more than ten years can overcome the issues regarding their work based on their experience, not the applicable regulation so that they tend to not comply with the existing SOP.

Suma'mur (2014) argued that someone with the experience of noticing hazards toward accident would get better in accordance with age, working period, and length of time he works at that place. The results of this research are in line with the statement argued by Suma'mur (2014) that the new workers often do not know the work profoundly yet so that they tend to finish their job without concerning the work safety.

\section{Worker Training and SOP Compliance}

The results of the study regarding the correlation between training and SOP compliance demonstrate that there is a correlation between both variables. Thus, it can be deduced that the high or low change in the training affects SOP compliance. According to the questionnaire results, there are still workers who do not attend the training that has a low level of SOP compliance. This research is in line with the one conducted by Patria (2017) that mentioned that there is a correlation between worker training and workers' compliance toward the SOP. It indicates that if the worker training is good, it will influence the workers' compliance toward the SOP in performing their work.

According to Suma'mur (2014), although the level of training is high, there is still the possibility of an accident. This situation occurs in the repetitive or monotonous work, particularly the problems related to time. This finding is in accordance with the situation and condition of the workers at the CEVD of PT X due to high work targets from daily to monthly, so several workers choose to behave unsafely to achieve such target, especially the work nature at the CEVD PT $\mathrm{X}$ is also monotonous.

The worker training is highly required to provide additional insight and knowledge toward the importance of working with complying with the existing SOP so that the workers can prevent occupational accidents and affect workplace safety. The training is not only able to increase workers' knowledge, but also their attitude, awareness, and ability to improve their skill in working, so that they will perform in accordance with the regulation established by the company.

\section{Knowledge and SOP Compliance}

The research results show that there is a correlation between knowledge and SOP compliance. It indicates that every change in the level of knowledge, either low, moderate, or high, can affect the workers' compliance in carrying out the SOP. The research conducted by Ulfa and Sarzuli (2016) on nurse compliance with the SOP of catheter installation at PKU Muhammadiyah Yogyakarta Hospital Unit II indicated that 21 out of 22 nurses who complied with the SOP were the nurses who acquired good knowledge. This research is not in line with the one conducted by Dewi (2010) on the workers at PT Suzuki Indomobil Motor-Roda 4 Plant Tambun II Bekasi which demonstrated that there was no significant correlation between knowledge and workers' compliance in carrying out the work SOP. This research is also in line with the one conducted by Wulansari (2017), which signified that there is a relatively strong correlation between knowledge and unsafe behavior.

The correlation between knowledge and SOP compliance indicates that the lower the level of knowledge, the more the workers commit unsafe behavior, and vice versa. The workers who do not understand the rules in working will work only based on their 
knowledge and experience. On the other hand, they also need sufficient knowledge regarding the related type of work to minimize unsafe behavior. The workers' knowledge needs to be improved, for the workers with the low and moderate levels of knowledge, so that they will be able to minimize the potential hazards generated from the unsafe behavior at work.

The interview results with one of the workers at PT X demonstrated that the company had made an effort to increase its workers' knowledge level with the establishment of Small Group Activity (SGA), that were all safety activities in every production division. SGA aims at monitoring all Occupational Safety and Health activities in the production processes. One of the programs is the members' voice activity, which is a system utilized to channel the workers' aspirations regarding safety at the workplace. For example, if there is a potential hazard that is threatening the workers, they will notice the hazard and write it on the board when they gather or in every morning talk. The hazard is then discussed further so that it can increase the workers' knowledge regarding the hazard. It is carried out to create the workers' safety habit. The workers were also demanded to improve every month.

\section{Motivation and SOP Compliance}

The research results regarding motivation and SOP compliance indicate that there was a correlation between both variables. Therefore, the workers' motivation could affect their compliance toward the company's SOP. These results are in line with the research conducted by Dewi (2010) on the workers at PT Suzuki Indomobil Motor-Roda 4 Plant Tambun II Bekasi which demonstrated that the workers' motivation had a significant correlation with compliance. These results also correspond to the research conducted by Tristanti (2017), who mentions that motivation was related to the compliance toward the work instruction, so that the higher the motivation, the higher the compliance.

Many workers who did not comply with the SOP was caused by their motivation that tends to be low. Therefore, the role of management is required in encouraging the work motivation in the forms of not only rewards, such as salary or incentive but also appreciation, such as the announcement of the best workers, so that other workers will be motivated in doing their work. Halimah (2010) argued that motivation in doing work in accordance with the SOP is required to achieve the company's goals and ensure the workers' safety. Therefore, in order to increase the workers' motivation, the encouragement both from the workers themselves and the management are required. The awareness of safety at work will grow from within so that the culture of Occupational Safety and Health (OSH) can be built easily.

According to Halimah (2010), the rewards given to workers will affect their motivation. With rewards, the workers will feel appreciated for what they have done for the company, and it will encourage them to work harder. The rewards given by the management can be in the form of improving the work motivation itself.

\section{CONCLUSION}

From the research results and discussion, it can be concluded that the workers' training was correlated with the their SOP compliance. Some workers who did not receive the training did not comply with the SOP. The workers' age was not correlated with the workers' SOP compliance. Every age level in this research indicated SOP non-compliance, meaning that all age ranges were potential not to comply with the SOP. The working period did not have any correlation with SOP compliance. Every level of working period in this research demonstrates SOP non-compliance with the SOP. Therefore, all levels of the working period were potential not to comply with the SOP. The workers' knowledge was related to the workers' compliance toward the SOP. Most of the workers who did not comply with the SOP were those who acquired a low knowledge level. The higher the knowledge level, the higher the workers' compliance toward the SOP. The workers' motivation was correlated with their SOP compliance. The majority of workers who did not comply with the SOP were those who had low motivation, meaning that the higher the motivation level, the higher the workers' SOP compliance.

\section{ACKNOWLEDGMENT}

The researcher would like to express her gratitude to God Almighty, research advisor, and parents as the greatest supporters in the 
process of writing this journal article. Special gratitude is also dedicated to the respondents at PT X, who were willing to participate in this research. Due to their participation, this journal article is completed successfully and is expected to be useful for the wider community, particularly for companies.

\section{REFERENCES}

Bird, F. E. and Germain, G. L. (1985) Practical Loss Control Leadership. Georgia: International Loss Control Institute, Inc.

Dewi, N. P. (2010) Factors Related to Employee Compliance in Implementing Work Procedure Standards (Standard Operational Procedure / SOP) in PT Suzuki Indomobil Motorized Wheel 4 Plant Tambun II Bekasi in 2010. Undergraduate Thesis. Jakarta: Faculty of Medicine and Health Science Syarif Hidayatullah State Islamic University Jakarta.

Halimah, S. (2010) Influence Factor's of Worker's Safety Behavior at PT. SIM PLANT Tambun II Year 2010. Undergraduate Thesis: Jakarta: Faculty of Medicine and Health Science Syarif Hidayatullah State Islamic University Jakarta.

Heinrich, H. W. (1980) Industrial Accident Prevention: A Scientific Approach. New York: McGraw-Hill Inc.

Kuswana, W. S. (2016) Ergonomics and Occupational Health and Safety. Bandung: PT. Remaja Rosdakarya.

Noviyanti, L. (2017) Analysis of the Relationship between Factors Causing Work Accidents and Unsafe Behavior in Welding Workers PT. PAL Indonesia (Persero) Surabaya Commercial Ship Division. Thesis: Surabaya: Faculty of Public Health Universitas Airlangga.

Patria, D. A. (2017) Relationship between Individual Characteristics and Personality Dimensions with the Occurrence of Unsafe Action (Study of the Mechanical and Gas Cutting Plate Division of PT. Gunawan Dianjaya Steel Tbk. Surabaya). Undergraduate Thesis: Surabaya: Faculty of Public Health Universitas Airlangga.

Suma'mur, P. K. (2014) Occupational Safety and Accident Prevention. Jakarta: Sagung Seto.
Tarwaka (2016) Basics of Work Safety and Accident Prevention in the Workplace. Surakarta: Harapan Press.

The Indonesian Social Security for Employment (2016) The Number of Work Accidents in Indonesia is Still High, Jakarta: The Indonesian Social Security for Employment.

Tristanti, S. (2017) Correlation between Antecedents and Consequences with Manpower Compliance Behavior for Forklift Operation Work Instructions at $P T$. $X$. Undergraduate Thesis: Surabaya: Facultyof Public Health Universitas Airlangga.

Ulfa, M. and Sarzuli, T. (2016) 'The Effect of Internal and External Factors on Nurses' Compliance in Implementing Standard Operating Procedures of Catheter Installation at PKU Muhammadiyah Yogyakarta Unit II Hospital', Jurnal Medicoeticolegal dan Manajemen Rumah Sakit, 5(1), pp. 49-55.

Wulansari, N. (2017) Factors Relating to Unsafe Actions in the Application of Machine Maintenance Procedures HMC (Harbor Mobile Crane) at PT BJTI Surabaya. Undergraduate Thesis: Surabaya: Faculty of Public Health Universitas Airlangga. 